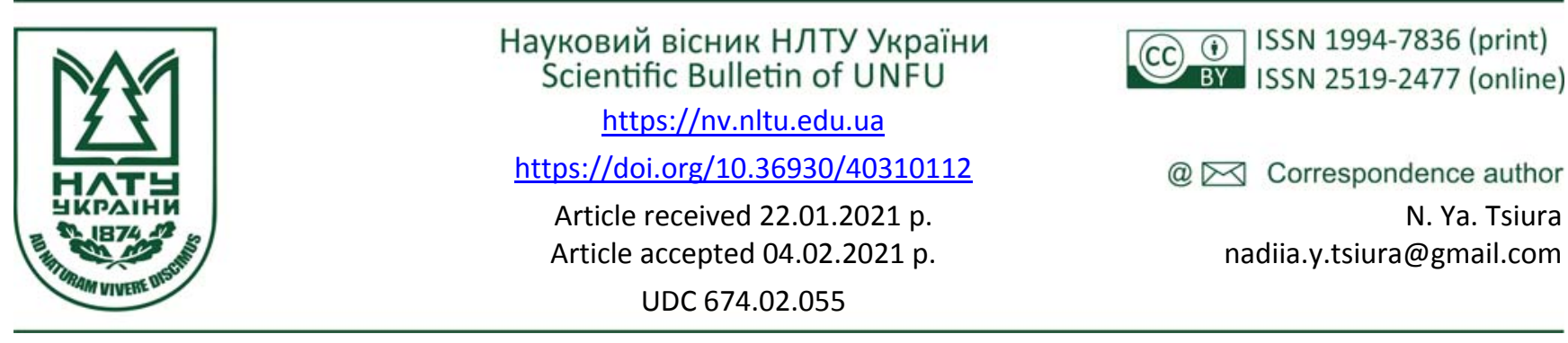

Н. Я. Цюра, Д. П. Кїнзера, В. М. Атаманюк, Р. Р. Госовський

Національний університет "Львівська політехніка", м. Львів, Украӥна

\title{
ДИНАМІКА ВИДАЛЕННЯ ВОЛОГИ З ФЕРУМ(ІІ) СУЛЬФАТ ГЕПТАГІДРАТУ ПІД ЧАС ПРОЦЕСУ ЗНЕВОДНЕННЯ ФІЛЬТРАЦІЙНИМ МЕТОДОМ
}

\begin{abstract}
Запропоновано фільтраційний метод дегідратації Ферум(II) сульфат гептагідрату з отриманням Ферум(II) сульфат тетрагідрату для його подальшої утилізації як вторинної сировини у промисловості, зокрема у виробництві пігментів. Обгрунтовано вибір способу дегідратації та, відповідно до технологічних вимог та властивостей матеріалу, встановлено діапазон зміни параметрів процесу сушіння й описано методики проведення експериментів. На базі даних, отриманих під час експериментальних досліджень, побудовано графічні залежності, які демонструють залежність зміни залишкової маси вологи в шарі матеріалу залежно від часу за різних швидкостей руху теплового агенту та за різних висот шару. Також подано залежності зміни температури теплового агенту на виході зі стаціонарного шару Ферум(II) сульфат гептагідрату, через який профільтровується тепловий агент. Аналіз цих результатів дав змогу переконатися в існуванні періодів часткового та повного насичення вологою теплового агенту. Внаслідок узагальнення отриманих даних запропоновано кінетичні рівняння для розрахунку зміни вологовмісту Ферум(II) сульфат гептагідрату в періоди повного та часткового насичення теплового агенту. Розраховано значення коефіцієнта сушіння, відносного коефіцієнта сушіння та швидкості сушіння за змінних параметрів теплоносія та різних висот шару матеріалу. Ці величини дали змогу розрахувати тривалість процесу дегідратації до моменту досягнення критичної вологості та загальну тривалість сушіння, а також запропонувати розрахункову залежність для визначення зміни вологовмісту Феруму(II) сульфат гептагідрату в часі в широкому діапазоні зміни параметрів процесу фільтраційного сушіння для періоду часткового насичення теплового агенту вологою. Ці результати використовують для розрахунку технологічних параметрів процесу дегідратації Ферум(II) сульфат гептагідрату та в процесі проєктування відповідної сушильної установки.
\end{abstract}

Ключові слова: залізний купорос; сушіння; стаціонарний шар; швидкість сушіння; вологовміст.

\section{Вступ}

Сульфатний метод виробництва є основним методом отримання $\mathrm{TiO}_{2}$ в більшості європейських країн [27]. Супутнім продуктом, що отримують внаслідок застосування такої технології, є Ферум(II) сульфат гептагідрат $\mathrm{FeSO}_{4} \cdot 7 \mathrm{H}_{2} \mathrm{O}$ (залізний купорос), отриманий способом кристалізації та відокремлення 3 розчину. На підприємствах накопичуються значні обсяги $\mathrm{FeSO}_{4} \cdot 7 \mathrm{H}_{2} \mathrm{O}-$ на тонну отриманого $\mathrm{TiO}_{2}$, як основного продукту, утворюється до 6 тонн $\mathrm{FeSO}_{4} \cdot 7 \mathrm{H}_{2} \mathrm{O}[18,24,27]$. Деяка кількість $\mathrm{FeSO}_{4} \cdot 7 \mathrm{H}_{2} \mathrm{O}$ застосовується для виробництва продукції для потреб сільського та лісового господарств $[14,16,24]$; хімічної промисловості - для синтезу фератів лугів $[14,16]$, отримання додатків до цементу та ферро-гіпсу [13, 26, 28, 32], виробництва теплоізоляційних матеріалів [28], коагулянтів для очищення стіч- них вод підприємств від хромових та ціаністих солей $[17,23]$, сульфатної кислоти [20]; гірничозбагачувальної - для збагачення вугілля, вилучення корисних компонентів 3 руд $[15,21]$; фармацевтичної - для виробництва препаратів для лікування і профілактики залізодефіцитної анемії [12] тощо. Однак значна частина $\mathrm{FeSO}_{4}$. $7 \mathrm{H}_{2} \mathrm{O}$ не знаходить належного застосування й залишається виробничим відходом, створюючи екологічну проблему. Тому розширення промислової сфери застосування $\mathrm{FeSO}_{4} \cdot 7 \mathrm{H}_{2} \mathrm{O}$, зокрема для виробництва Ферумоксидних пігментів, є питанням актуальним [5, 11, 31].

Важливе значення має дослідження закономірностей перебігу процесу дегідратації кристалів залізного купоросу. Адже результати експериментів та їх подальше математичне опрацювання дадуть змогу запроєктувати відповідне обладнання, яке забезпечить стабілізацію цього багатотоннажного відходу і зробить можли-

Інформація про авторів:

Цюра Надія Ярославівна, асистент, кафедра хімічної інженерії. Email: nadiia.y.tsiura@gmail.com; https://orcid.org/0000-0001-7272-3871

Кіндзера Діана Петрівна, канд. техн. наук, доцент, кафедра хімічної інженерії. Email: kindzera74@ukr.net; https://orcid.org/0000-0002-9350-1423

Атаманюк Володимир Михайлович, д-р техн. наук, професор, завідувач кафедри хімічної інженерії. Email: atamanyuk@ukr.net; https://orcid.org/0000-0002-8707-2319

Госовський Роман Романович, канд. техн. наук, асистент, кафедра хімічної інженерії. Email: roma5477@meta.ua; https://orcid.org/0000-0003-4837-2957

Цитування за ДСту: Цюра Н. Я., Кіндзера Д. П., Атаманюк В. М., Госовський Р. Р. Динаміка видалення вологи з Ферум(ІІ) сульфат гептагідрату під час процесу зневоднення фільтраційним методом. Науковий вісник НлтУ України. 2021, т. 31, № 1. С. 74-79.

Citation APA: Tsiura, N. Ya., Kindzera, D. P., Atamanyuk, V. M., \& Hosovskyiy, R. R. (2021). Dynamics of moisture removal from iron(II) sulfate heptahydrate during the drying process by filtration method. Scientific Bulletin of UNFU, 31(1), 74-79. https://doi.org/10.36930/40310112 
вим процес його утилізації.

Для виробництва широкого спектра Ферумоксидних пігментів, перед промисловістю постає практичне завдання висушування кристалогідратів $\mathrm{FeSO}_{4} \cdot 7 \mathrm{H}_{2} \mathrm{O}$, пов'язане 3 необхідністю видалення вільної вологи та кристалізаційної води, що зумовлює значні енерговитрати під час реалізації процесів сушіння у барабанних сушарках $[2,7]$, сушарках киплячого шару та в мікрохвильовому полі [22].

Об'єкт дослідження - технологічний процес вилучення трьох молекул води з $\mathrm{FeSO}_{4} \cdot 7 \mathrm{H}_{2} \mathrm{O}$, відбувається в діапазоні температур $60-65^{\circ} \mathrm{C}$ у повітряному середовищі. При цьому відбувається утворення Феруму(II) сульфат тетрагідрату $\mathrm{FeSO}_{4} \cdot 4 \mathrm{H}_{2} \mathrm{O}[18,27]: \mathrm{FeSO}_{4} \cdot 7 \mathrm{H}_{2} \mathrm{O}=$ $\mathrm{FeSO}_{4} \cdot 4 \mathrm{H}_{2} \mathrm{O}+3 \mathrm{H}_{2} \mathrm{O}$

Предмет дослідження - динаміка процесу зневоднення $\mathrm{FeSO}_{4} \cdot 7 \mathrm{H}_{2} \mathrm{O}$ способом профільтровування теплового агенту крізь стаціонарний шар матеріалу в напрямку до перфорованої перегородки.

Метою роботи - встановлення розрахункових залежностей, які дадуть змогу обчислити зміну вологовмісту матеріалу в часі залежно від змінних параметрів швидкості руху теплового агенту та висоти стаціонарного шару Феруму(II) сульфат гептагідрату.

Для досягнення зазначеної мети визначено такі основні завдання дослідження:

- дослідити вплив швидкості руху теплового агенту та висоти стаціонарного шару Феруму(II) сульфат гептагідрату на динаміку видалення вологи зі стаціонарного шару та узагальнити результати;

- обгрунтувати вибір способу та параметрів сушіння Феруму(II) сульфат гептагідрату.

Наукова новизна отриманих результатів дослідження - теоретично обгрунтовано та експериментально підтверджено вплив режиму проведення зневоднення залізного купоросу на динаміку видалення вологи зі стаціонарного шару матеріалу. Вперше розраховано коефіцієнти сушіння та отримано рівняння для прогнозування зміни вологовмісту залізного купоросу під час його зневоднення за змінних параметрів шару та теплового агенту.

Практична значущчість результатів дослідження отримані розрахункові залежності дають змогу прогнозувати перебіг процесу за змінних умов. Це дає підстави для проєктування та здійснення процесу зневоднення Феруму(II) сульфат гептагідрату в промислових умовах способом фільтраційного сушіння, який характеризується ефективністю та екологічністю.

Аналіз останніх досліджень та публікацій. Розширення сфери застосування Феруму(II) сульфат гептагідрату тісно пов'язане із впровадженням нових технологічних рішень щодо зменшення споживання енергії на стадії сушіння у виробничих лініях [2, 5, 12, 11, 31]. Застосування фільтраційного методу сушіння для Ферум (II) сульфат гептагідрату дає змогу інтенсифікувати процес його дегідратації завдяки досягненню високих значень коефіцієнтів тепло- та масопередачі внаслідок інтенсивного контакту між рухомим тепловим агентом та продуктом, що розташовується на перфорованій решітці та зменшити енергетичні витрати на реалізацію останнього, порівняно зі зазначеними промисловими методами $[7,9]$. Окрім цього, охолодження кристалів на завершальному етапі сушіння способом профільтровування холодного повітря крізь шар матеріалу знижує ризик виникнення злежуваності продукту [15].
Для інтенсифікації сушіння Феруму(II) сульфат гептагідрату фільтраційним методом потрібно дослідити вплив швидкості фільтрування теплового агенту та геометричних розмірів стаціонарного шару на перебіг процесу $[1,10]$. Варіювання технологічними параметрами процесу фільтраційного сушіння Феруму(II) сульфат гептагідрату дає змогу змінювати енергозатрати на реалізацію останнього. Оскільки процес сушіння є енергоємним, то оптимальний режим фільтраційного сушіння повинен характеризуватися такою швидкістю руху теплового агенту, а також висотою шару матеріалу, за яких енерговитрати на реалізацію процесу були б мінімальними та тривалість сушіння була б незначною. Зважаючи на те, що у літературі відсутня інформація щодо кінетичних закономірностей фільтраційного сушіння Феруму(II) сульфат гептагідрату та динаміки видалення вологи зі стаціонарного шару, ми проводили експериментальні дослідження саме в цьому напрямі.

Обгрунтування вибору параметрів процесу фільтраційного сушіння. Вибір температури теплового агенту $335 \pm 0,5 \mathrm{~K}$ зумовлювався фізико-хімічними властивостями Ферум(II) сульфат гептагідрату - здатністю до відщеплення трьох молекул води у вузькому діапазоні температур.

Діапазон зміни швидкостей теплового агенту $0,46 \leq v_{0} \geq 1,61 \mathrm{~m} / \mathrm{c}$, який відповідав перепадам тисків для сухого матеріалу $1210 \leq \Delta p_{c} \geq 7620$ Па, обрано із врахуванням продуктивності промислових вентиляторів та зважаючи на те, що в промислових установках загальна площа зони сушіння може становити 4-6 м².

Діапазон зміни висоти стаціонарного шару Феруму(II) сульфат гептагідрату $30 \cdot 10^{-3} \leq H \geq 120 \cdot 10^{-3}$ м обрано згідно з рекомендаціями, наведеними в роботі [9], де мінімальна висота шару повинна бути не меншою ніж $20 d_{\text {часm }}$ та із міркувань забезпечення максимально можливого рівномірного прогрівання шару.

На основі виконаних розрахунків енергозатрат на реалізацію процесів фільтраційного сушіння Феруму(II) сульфат гептагідрату за різних швидкостей теплового агенту та висот шару матеріалу, визначено оптимальні параметри, за яких енерговитрати є мінімальними, зокрема: $H=60 \cdot 10^{-3}$ м та $v_{0}=0,86 \mathrm{~m} / \mathrm{c}$. Саме ці параметри було обрано в ролі базових для дослідження динаміки видалення вологи з Феруму(II) сульфат гептагідрату.

Дослідження динаміки видалення вологи $з$ Феруму(II) сульфат гептагідрату. Експериментальні дослідження проводили не дослідній установці відповідно до запропонованої методики [1]. Основними елементами установки фільтраційного сушіння $є$ : вентилятор та калорифер для подачі та нагрівання теплового агенту; запірний та регулятивні вентилі для подачі та регулювання витрати теплового агенту; вакуум-насос для створення розрідження у системі; ресивер для згладжування пульсацій; контейнер для формування стаціонарного шару матеріалу. Установка оснащена регулятивними та вимірювальними пристроями: електронним терморегулятором SESTOS D1S, термопарами з індикатором температури RT8-1000, електронним ротаметром RPF-I, електронними вагами AXIS-AD3000.

Для реалізації ізотермічної дегідратації Феруму(II) сульфат гептагідрату вмикали вентилятор та калорифер для нагрівання теплового агенту до температури 
$335 \pm 0,5$ К. Значення температури контролювали за допомогою електронного терморегулятора SESTOS D1S. Після встановлення належного значення температури теплового агенту вмикали вакуум-насос. Контейнер, із сформованим шаром залізного купоросу, встановлювали на ресивер, відкривали запірний вентиль і проводили дослідження. За допомогою регулятивного вентиля встановлювали необхідні витрати теплового агенту, який профільтровувався через шар матеріалу. Витрати теплового агенту вимірювали за допомогою електронного ротаметра RPF-I. Дослідження виконували за різних фіктивних швидкостей руху теплового агенту $v_{0}$ $(0,46 ; 0,61 ; 0,86 ; 1,11 ; 1,61 \mathrm{~m} / \mathrm{c})$ за сталої висоти шару $H=60 \cdot 10^{-3} \mathrm{M}$; за різних висот шару матеріалу $H\left(30 \cdot 10^{-}\right.$ ${ }^{3} ; 60 \cdot 10^{-3} ; 90 \cdot 10^{-3} ; 120 \cdot 10^{-3}$ м) за сталої фіктивної швидкості фільтрування теплового агенту $v_{0}=1,61 \mathrm{~m} / \mathrm{c}$.

Під час досліджень зміну маси матеріалу через певні проміжки часу визначали ваговим методом за допомогою електронних ваг AXIS-AD3000. Експерименти продовжували до досягнення сталої маси зразка залізного купоросу. Кожен експеримент проводили тричі для отримання достовірних даних. Зміну маси вологи в шарі Феруму(II) сульфат гептагідрату в процесі сушіння визначали розрахунковим методом.

Вимірювання температури теплового агенту на виході зі шару матеріалу. Для визначення температури сушильного агенту на виході зі стаціонарного шару Феруму(II) сульфат гептагідрату з висотами $H 30 \cdot 10^{-3}$; $60 \cdot 10^{-3} ; 90 \cdot 10^{-3} ; 120 \cdot 10^{-3} \mathrm{M}$, використовували три термопари, які були встановлені на відстані 0,2 м від перфорованого дна контейнера. Термопари встановлювали під кутом $120^{\circ}$ одна до одної на відстані 0,$1 ; 0,2$ і 0,3 м від центру контейнера. Температури на виході зі стаціонарного шару автоматично реєструвалась за допомогою індикатора температури RT8-1000 з комп'ютерним обробленням даних.

Експерименти припиняли, коли температура на виході зі стаціонарного шару досягала максимуму і припиняла змінюватись. Кожен експеримент проводили тричі для отримання достовірних даних.

\section{Результати дослідження та їх обговорення}

Експериментальні дані дослідження динаміки видалення вологи з Феруму(II) сульфат гептагідрату подано у вигляді залежності зміни залишкової маси вологи в шарі матеріалу від часу $G=f(\tau)$.

$\mathrm{У}$ початковий момент сушіння $\tau=0$ маса вологи (поверхневої та кристалізаційної) у шарі Феруму(II) сульфат гептагідрату висотою $H=60$ мм становила 0,068 кг. Дослідження динаміки виділення вологи зі шару матеріалу за різних швидкостей фільтрування теплового агенту (рис. 1) показали, що зростання швидкості теплового агенту призводить до збільшення кількості вологи, що видаляється зі шару за одиницю часу. Інтенсивність сушіння - кількість видаленої вологи зі шару за одиницю часу, визначається за тангенсом кута нахилу прямолінійних частин кривих $G=f(\tau)$ до осі абсцис. Зміна кута нахилу кривих свідчить проте, що у періоді повного насичення теплового агенту вологою інтенсивність видалення вологи зростає із збільшенням швидкості руху теплового агенту.

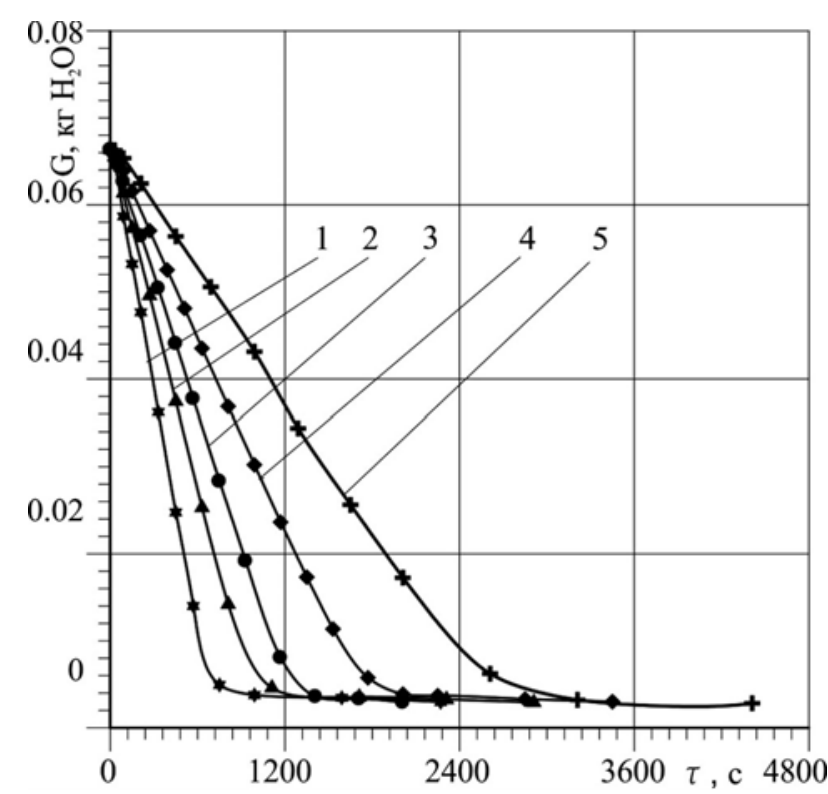

Рис. 1. Динаміка видалення вологи з шару Феруму(II) сульфат гептагідрату (залежність зміни залишкової маси вологи в шарі матеріалу залежно від часу) за різних швидкостей руху теплового агенту: $1-v_{0}=1,61 \mathrm{M} / \mathrm{c} ; 2-v_{0}=1,11 \mathrm{M} / \mathrm{c} ; 3-$ $v_{0}=0,86 \mathrm{M} / \mathrm{c} ; 4-v_{0}=0,61 \mathrm{M} / \mathrm{c} ; 5-v_{0}=0,46 \mathrm{M} / \mathrm{c} ;(H=60$ мM, $T=335 \mathrm{~K})$

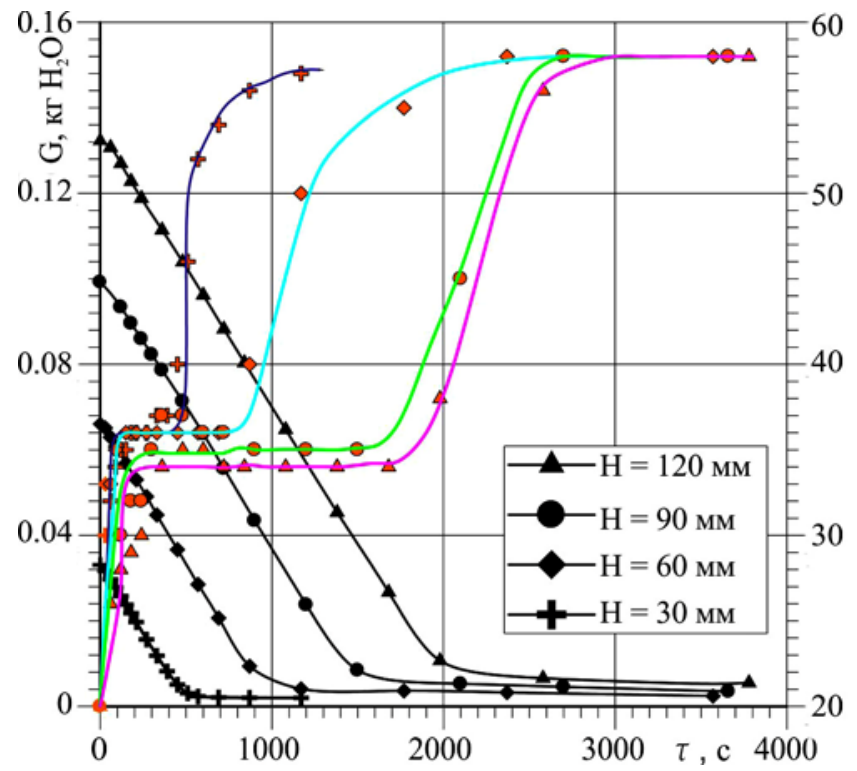

Рис. 2. Динаміка видалення вологи зі шару Феруму(II) сульфат гептагідрату (залежність зміни залишкової маси вологи в шарі матеріалу залежно від часу) за різних висот шару та зміни температури теплового агенту на виході із стаціонарного шару ( $\left.v_{0}=0,86 \mathrm{M} / \mathrm{c} ; T=335 \mathrm{~K}\right)$

Як видно із графічної залежності, поданої на рис. 2, у початковий момент сушіння $\tau=0$ кількість вологи в шарі $є$ пропорційною його висоті - 3 ростом висоти шару зростає. Паралельність прямолінійних ділянок кривих свідчить про те, що динаміка видалення вологи не залежить від висоти шару, а визначається величиною сушильного потенціалу теплового агенту, який залежить від температури та об'ємної витрати останнього.

На рис. 2 також подано графічні залежності, що характеризують зміну температури теплового агенту, яка вимірювалася на виході зі шарів матеріалу різної висоти. Під час фільтрування сушильного агенту крізь шар матеріалу, тепловий агент рівномірно розподіляється по їх об'єму віддаючи тепло i, як результат - весь матеріал 
бере участь у процесі теплопередачі. У перші секунди процесу сушіння, температура на виході зі шару зростає, що свідчить про прогрівання матеріалу, після чого iіi значення залишається сталим, про що свідчать прямолінійні горизонтальні ділянки на графічних залежностях, довжина яких зростає зі збільшенням висоти шару матеріалу. Сталість значення температури теплового агенту на виході зі шару характеризує період повного насичення теплового агенту вологою. Після досягнення матеріалом значення критичного вологовмісту $W_{\kappa p}$, настає період часткового насичення теплового агенту вологою й у цьому періоді температура теплового агенту на виході з шару матеріалу зростає. Досягнення сталого значення температури на виході зі шару, дещо нижчого від температури на вході у шар, свідчить про припинення процесу сушіння.

Як зазначено вище, подані на рис. 1 та 2 графічні залежності характеризуються наявністю двох ділянок, що відповідають періодам повного та часткового насичення теплового агенту вологою. Точка переходу періоду повного насичення теплового агенту вологою у період часткового насичення характеризується значенням критичного вологовмісту $W_{\kappa p}$.

Для визначення значення $W_{\kappa p}$. результати досліджень було подано у координатах $\lg \left(W-W_{p}\right)=f(\tau)$, де $W, W_{p}$ - рухоме та рівноважне значення вологовмісту матеріалу, кг/кг; $\tau$ - час сушіння, $c$ та знайдена ордината точки перетину двох прямих $x$, що відповідають періодам повного і часткового насичення теплового агенту вологою і використана залежність: $W_{\kappa p}=10^{x}+W_{p}$. Отже, значення $W_{\kappa p}=0,043$ кг $\mathrm{H}_{2} \mathrm{O} /$ кг сух. мат.

На основі узагальнення результатів дослідження, отримано кінетичне рівняння (1), яке дає змогу розрахувати зміну вологовмісту Феруму(II) сульфат гептагідрату в часі в періоді повного насичення теплового агенту вологою в діапазоні зміни висот від $30 \cdot 10^{-3}$ до $120 \cdot 10^{-3}$ м та швидкостей теплового агенту від 0,46 до 1,61 м/с:

$$
\frac{W}{W_{0}}=1-6,5 \cdot 10^{-4} \Delta P_{c}^{0,2} \cdot \tau \cdot e^{-15,75 \cdot H} .
$$

Узагальнення результатів дослідження для періоду часткового насичення теплового агенту вологою. Рівняння кривої швидкості сушіння в періоді часткового насичення теплового агенту вологою має такий вигляд [1]:

$$
-\frac{d W}{d \tau_{0}}=K \cdot\left(W-W_{p}\right)
$$

де $K$ - коефіцієнт сушіння, $1 / \mathrm{c}$, який розраховують як

$$
K=\chi \cdot N \text {, }
$$

де: $\chi-$ відносний коефіцієнт сушіння, який $\epsilon$ постійним для досліджуваного матеріалу, кг/кг; $N$ - швидкість сушіння у періоді повного насичення теплового агенту вологою, (кг/кг'с).

Подано рівняння (2) в інтегральній формі

$$
\frac{W-W_{p}}{W_{\kappa p}-W_{p}}=e^{-K\left(\tau-\tau_{k p}\right)} .
$$

Прологарифмувавши рівняння (4), отримаємо

$$
\ln \frac{W-W_{p}}{W_{\kappa p}-W_{p}}=f\left(\tau-\tau_{\kappa p}\right) .
$$

Для визначення коефіцієнта сушіння $K$ експериментальні значення подавали у координатах $\ln \frac{W-W_{p}}{W_{\kappa p}-W_{p}}=f\left(\tau-\tau_{\kappa p}\right) \quad$ (рис. 3 та 4) і за тангенсом кута нахилу прямих визначали значення останнього.

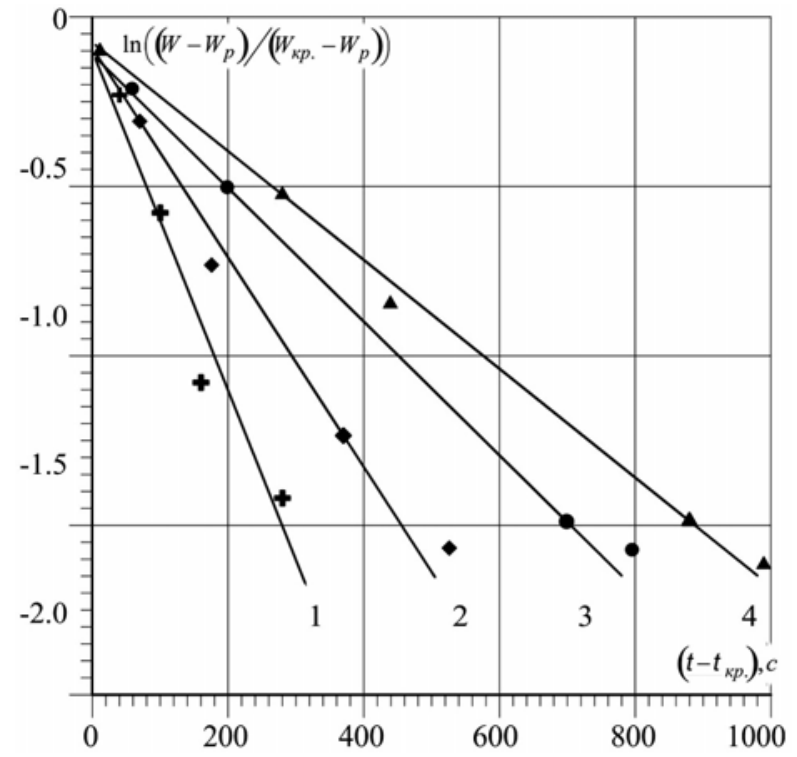

Рис. 3. Визначення коефіцієнта сушіння К: $\left(v_{0}=0,86 \mathrm{~m} / \mathrm{c}\right.$;

$T=335 \mathrm{~K}) ; 1-H=30 \cdot 10^{-3} \mathrm{M}, 2-H=60 \cdot 10^{-3}$ м, $3-$

$H=90 \cdot 10^{-3} \mathrm{M}, 4-H=120 \cdot 10^{-3} \mathrm{M}$

Як видно з графічних залежностей, поданих на рис. 3 та 4, коефіцієнт сушіння К залежить від висоти шару Феруму(II) сульфат гептагідрату та від швидкості руху теплового агенту.

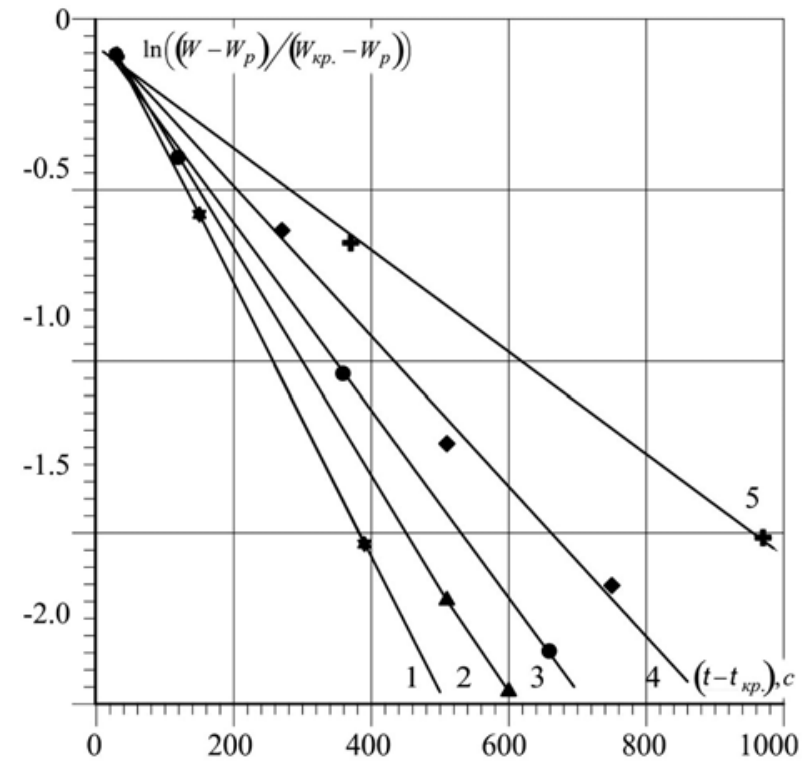

Рис. 4. Визначення коефіцієнта сушіння К: $\left(H=60 \cdot 10^{-3} \mathrm{~m}\right.$;

$T=335 \mathrm{~K}) ; 1-v_{0}=1,61 \mathrm{~m} / \mathrm{c} ; 2-v_{0}=1,11 \mathrm{~m} / \mathrm{c} ; 3-$

$v_{0}=0,86 \mathrm{~m} / \mathrm{c} ; 4-v_{0}=0,61 \mathrm{~m} / \mathrm{c} ; 5-v_{0}=0,46 \mathrm{~m} / \mathrm{c}$

Залежність (5) із врахуванням залежності (3) можна подати у такому вигляді:

$$
\frac{W-W_{p}}{W_{\kappa p}-W_{p}}=e^{-\chi N\left(\tau-\tau_{\kappa p}\right)} .
$$

Значення коефіцієнтів сушіння $K$ (отриманих 3 рис. 3 та 4) та швидкостей сушіння у періоді повного насичення теплового агенту вологою $N$ наведено у таблиці. 
Швидкість сушіння $N$ у періоді повного насичення теплового агенту вологою визначали за залежністю

$$
N=\frac{W_{0}-W_{\kappa p}}{\tau_{\kappa p}}=\frac{\left(W_{0}-W_{\kappa p}\right) \cdot \alpha \cdot e^{-a \cdot H}}{1-W_{\kappa p} / W_{0}} .
$$

Таблиця. Швидкість сушіння $\mathbf{N}$ у періоді повного насичення теплового агенту та значення коефіціснта сушіння К

\begin{tabular}{|c|c|c|c|c|c|}
\hline \multicolumn{3}{|c|}{$T=335 \mathrm{~K}$} & \multicolumn{3}{c|}{$v_{0}=0,86 \mathrm{м} / \mathrm{c}$} \\
\hline$v_{0}, \mathrm{M} / \mathrm{c}$ & $\begin{array}{c}N \cdot 10^{4}, \\
\mathrm{\kappa} /(\mathrm{\kappa} \Gamma \cdot \mathrm{c})\end{array}$ & $\begin{array}{c}K \cdot 10^{3}, \\
1 / \mathrm{c}\end{array}$ & $\begin{array}{c}H \cdot 10^{3}, \\
\mathrm{M}\end{array}$ & $\begin{array}{c}N \cdot 10^{4}, \\
\mathrm{\kappa} /(\mathrm{\kappa} \Gamma \cdot \mathrm{c})\end{array}$ & $\begin{array}{c}K \cdot 10^{3}, \\
1 / \mathrm{c}\end{array}$ \\
\hline 0,46 & 0,9 & 1,5 & 30 & 4,6 & 5,1 \\
\hline 0,61 & 1,32 & 2,2 & 60 & 2,4 & 3,1 \\
\hline 0,86 & 1,84 & 2,7 & 90 & 1,5 & 1,97 \\
\hline 1,11 & 2,34 & 3,3 & 120 & 1,1 & 1,61 \\
\hline 1,61 & 3,34 & 4,0 & & & \\
\hline
\end{tabular}

Відносний коефіцієнт сушіння $\chi \epsilon$ величиною сталою для досліджуваного матеріалу і його числове значення дає змогу розрахувати час сушіння Феруму(II) сульфат гептагідрату, а також визначити параметри для здійснення фільтраційного процесу сушіння. Для визначення відносного коефіцієнта сушіння $\chi$, результати подавали у вигляді графічної залежності $K=f(N)$ (рис. 5) і значення коефіцієнта визначали за тангенсом кута нахилу прямої.

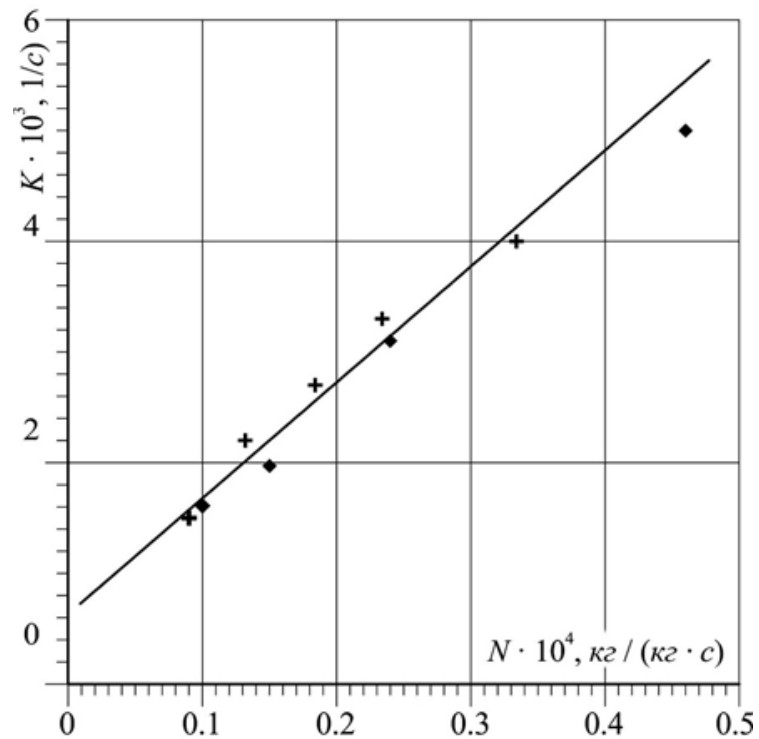

Рис. 5. Залежність коефіцієнта сушіння К від швидкості сушіння $N$

3 рис. 5 визначено відносний коефіцієнт сушіння $\chi$, який для Феруму(II) сульфат гептагідрату дорівнює $\chi=10,47$ кг/кг. Виходячи з рівняння (6) та враховуючи значення $\chi$, виведено залежність для розрахунку зміни вологовмісту Феруму(II) сульфат гептагідрату в часі у широкому діапазоні зміни параметрів процесу сушіння для періоду часткового насичення теплового агенту вологою:

$$
W=\left(W_{\kappa p}-W_{p}\right) \cdot e^{-10,47 \cdot N \cdot\left(\tau-\tau_{\kappa p}\right)}+W_{p} .
$$

Оскільки значення часу досягнення критичного вологовмісту є функцією критичного вологовмісту, тобто $\tau_{\kappa p}=f\left(W_{\kappa p}\right)$, то згідно зі залежністю (7) значення останнього можна розрахувати як

$$
\tau_{\kappa p}=\frac{W_{0}-W_{p}}{N} .
$$

Із врахуванням залежності (9) залежність (8) можна записати у такому вигляді:

$$
W=\left(W_{\kappa p}-W_{p}\right) \cdot \operatorname{Exp}\left(-10,47 \cdot N \cdot\left(\tau-\frac{W_{0}-W_{k p}}{N}\right)\right)+W_{p} .
$$

\section{Висновки}

Досліджено динаміку видалення вологи 3 Феруму(II) сульфат гептагідрату під час процесу зневоднення фільтраційним методом за різних швидкостей руху теплового агенту (див. рис. 1) та висот шару матеріалу (див. рис. 2), а також зміну температури теплового агенту на виході із стаціонарного шару (див. рис. 2). 3 рис. 3 та 4 визначено значення коефіцієнтів $K, 1 / \mathrm{c}$ та швидкостей сушіння $N$, кг/кг·с для періоду повного насичення теплового агенту вологою, які наведено у таблиці. 3 графічної залежності (див. рис. 5) визначено відносний коефіцієнт сушіння $\chi=10,47$ кг/кг, який $є$ постійним для досліджуваного матеріалу. Запропонована розрахункова залежність

$$
W=\left(W_{\kappa p}-W_{p}\right) \cdot \operatorname{Exp}\left(-10,47 \cdot N \cdot\left(\tau-\left(W_{0}-W_{\kappa p}\right) / N\right)\right)+W_{p}
$$

для визначення зміни вологовмісту Феруму(II) сульфат гептагідрату в часі у широкому діапазоні зміни параметрів процесу фільтраційного сушіння для періоду часткового насичення теплового агенту вологою.

\section{References}

1. Atamaniuk, V., \& Humnytskyi, Ya. (2013). Naukovi osnovy filtratsiinoho sushinnia dyspersnykh materialiv, 255 p. [In Ukrainian].

2. Barsukova, A. V., Vakal, S. V., \& Karpovich, E. A. (2014). Opredelenie optimalnykh uslovii tekhnologii po pererabotke osnovnogo otkhoda titanovogo proizvodstva. Izvestiia $M G T U, 2(20)$, 97101. [In Russian].

3. Chao Li, Jun-Jie Liao, Yang Yin, Qiong Mo, Li-Ping Chang, \& Wei-Ren Bao. (2018). Kinetic analysis on the microwave drying of different forms of water in lignite. Fuel Processing Technology, 176, 174-181. https://doi.org/10.1016/j.fuproc.2018.03.017

4. Fanhui Guo, Hu Liu, Yang Guo, Yixin Zhang, Jian Li, Xu Zhao, \& Jianjun Wu. (2021). Occurrence modes of water in gasification fine slag filter cake and drying behavior analysis. A case study. Journal of Environmental Chemical Engineering, 9(1). https://doi.org/10.1016/j.jece.2020.104585

5. Gelperin, N. I. (1981). Osnovnye protcessy i apparaty khimicheskoi tekhnologii, 812 p. [In Russian].

6. Georgiou, D., Aivazidis, A., Hatiras, J., \& Gimouhopoulos, K. (2003). Treatment of cotton textile wastewater using lime and ferrous sulfate. Water Research, 37(9), 2248-2250. https://doi.org/10.1016/S0043-1354(02)00481-5

7. Glouannec, P., Salagnac, P., Guézenoc, H., \& Allanic, N.. (2008). Experimental study of infrared-convective drying of hydrous ferrous sulphate. Powder Technology, 187, 280-288. https://doi.org/10.1016/i.powtec.2008.03.007

8. Guarini, G. G. T., \& Rustici, M. (1988). Heating rate and the dehydration of $\alpha \cdot \mathrm{NiSO}_{4} \cdot 6 \mathrm{H}_{2} \mathrm{O}$ single crystals. Journal of Thermal Analysis, 34, 487-495. https://doi.org/10.1007/BF01913189

9. Hosovskyi, R., Kindzera, D., \& Atamanyuk, V. (2016). Diffusive Mass Transfer during Drying of Grinded Sunflower Stalks. Chemistry \& Chemical Technology, 10(4), 459-464. https://doi.org/10.23939/cte2019.01.105

10. Hosovskyi, R., Kindzera, D., Atamaniuk, V. (2017). Vnutrishnodyfuziine masoperenesennia pid chas filtratsiinoho sushinnia podribnenoi parenkhimnoi tkanyny stebel soniashnyka. Scientific Bulletin of UNFU, 27(6), 112-116. https://doi.org/10.15421/40270622

11. Ivanov, V. G. (2004). Utilizatciia otkhodov sulfata zheleza. Sotrudnechestvo dlia resheniia problem otkhodov. Tezisy dokladov konferentcii s mezhdunarodnym uchastiem, (pp. 162-163). Kharkov. [In Russian]. 
12. Kanari, N. (2008). Method of Producing Ferrates (VI). French Patent No 2905 609, 14 March.

13. Kanari, N., Evrard, O., \& Neveux, N. (2001). Recycling ferrous sulfate via super-oxidant synthesis. The Journal of The Minerals, 53, 32-33. https://doi.org/10.1007/s11837-001-0191-8

14. Kanari, N., Filippova, I., Diot, F., Mochón, J., Ruiz-Bustinza, I., Allain, E., \& Yvon, J. (2014). Utilization of a waste from titanium oxide industry for the synthesis of sodium ferrate by gas-solid reactions. Thermochim. Acta, 575, 219-225. https://doi.org/10.1016/j.tca.2013.11.008

15. Kanari, N., Ostrosi, O., Ninane, N., Neveux, N., \& Evrard, O. (2005). Synthesizing alkali ferrates using a waste as a raw material. The Journal of The Minerals, 57, 39-42.

16. Karpovich, Ye. A., \& Zarechennyi, V. G. (2001). Vovlechenie v proizvodstvo udobrenii kislogo zheleznogo kuporosa. Ekologiia $i$ zdorove cheloveka. Okhrana vodnogo $i$ vozdushnogo basseinov. Utilizatciia otkhodov, 2, 396-398. [In Russian].

17. Kruhlova, N. O. (2014). Utylizatsiia shlamiv vyrobnytstva tytanooksydnykh pihmentiv yak zasib znyzhennia tekhnohennoho navantazhennia na dovkillia. Candidate Dissertation of Technical Sciences (21.06.01 - Ecological safety), 160 p. [In Ukrainian].

18. Kruhlova, N. O., \& Bakhariev, V. S. (2015). Ekolohichno bezpechna tekhnolohiia pereroblennia shlamiv vyrobnytstva tytanooksydnykh pihmentiv. Ecological safety, 2(20), 69-76. [In Ukrainian].

19. Liangzhi Xia, Hongchun Zhang, Baohe Wang, Caiyuan Yu \& Xinxin Fan. (2017). Experimental and numerical analysis of oil shale drying in fluidized bed. Drying Technology, 35(7), 802-814. https://doi.org/10.1080/07373937.2016.1218345

20. Marina, V. Savchenko-Pererva, \& Hanna, Y. Barsukova. (2020). Reducing The Technogenic Load On The Environment Due To The Technical Solution For The Disposal Of Iron Sulphate. Journal of Chemistry and Technologies, 28(2), 168-176. https://doi.org/10.15421/082018

21. Ndue Kanari, Nour-Eddine Menad, Etleva Ostrosi, Seit Shallari, Frederic Diot, Eric Allain, \& Jacques Yvon. (2018). Thermal Behavior of Hydrated Iron Sulfate in Various Atmospheres. Metals, 8, 1084. https://doi.org/10.3390/met8121084

22. Nizov, V. A., \& Aisautova, K. A. (2017). Osobennosti obezvozhivaniia kristallogidratov $\mathrm{v}$ mikrovolnovom pole na primere medno- go kuporosa "Young Scientist". Chemistry, 9(143), 111-112. [In Russian].

23. Nykyforov, A. P. (2002). Dobavky dlia betona. Sostoianye y perspektyvy. Building constructions, 56, 186-190. [In Ukrainian].

24. Plyshevskii, Iu. S., Tkachov, K. V., \& Garkunov, N. V. (1998). Ispolzovanie zheleznogo kuporosa - otkhoda, obrazuiushhegosia $\mathrm{v}$ protcesse polucheniia dioksida titana i travleniia zheleza dlia polucheniia sulfata kaliia i "zheleznogo" koagulianta. Ekaterinburg, 110 p. [In Russian].

25. Rongtang Liu, Ming Liu, Xiaoqu Han, \& Junjie Yan. (2020). Drying characteristics and kinetics analyses for Yimin lignite at various https://doi.org/10.1080/07373937.2020.1729174 temperature.

26. Sharma, S. K., Chio, C., \& Muenow, D. W. (2006). The hydrates and deuterates of ferrous sulfate $\left(\mathrm{FeSO}_{4}\right)$ : a Raman spectroscopic study. Lunar and Planetary Science Conference, XXXVII. Paper 1078. https://doi.org/10.1002/jrs. 1623

27. Skomorokha, V. N., Zarechnyi, V. G., \& Vorobeva, I. P. (2002). Proizvodstvo dvuokisi titana pigmentnoi sulfatnym sposobom. Sumy, 203 p. [In Russian].

28. Sobol, Kh. S., Markiv, T. Ye., Sanytskyi, M. A., \& Kohuch, H. V. (2003). Vplyv aktyvnykh mineralnykh dodatkiv na vlastyvosti kompozytsiinykh tsementiv. Bulletin of the National University "Lviv Polytechnic". Series: Chemistry, Technology of Substances and their Application, 488, 274-278. [In Ukrainian].

29. Straszko, J., Olszak-Humienik, M., \& Możejko, J. (1997). Kinetics of thermal decomposition of $\mathrm{ZnSO}_{4} \cdot 7 \mathrm{H}_{2} \mathrm{O}$. Thermochimica Acta, 292(1-2), 145-150. https://doi.org/10.1016/S00406031(96)03114-0

30. Tong Wang, Kenneth, A. Debelak, \& John, A. Roth. (2007). Dehydration of iron(II) sulfate heptahydrate. Thermochimica Acta, 462(1-2), 89-93. https://doi.org/10.1016/j.tca.2007.07.001

31. Yavorskyi, V. T., Kalymon, A. B., Rubai, O. I. (2015). A study of the effect of iron (III) compoundson oxidation of iron(II) ions by atmospheric oxygen. The Journal of The Minerals, 6(76), 13 https://doi.org/10.15587/1729-4061.2015.47460

32. Zarechenyi, V. H. (2005). Utylizatsiia zalizovmisnykh vidkhodiv vyrobnytstva pihmentnoho tytanu (IV) oksydu. Abstract of candidate dissertation for technical sciences (21.06.01 - Ecological safety). Lviv, 20 p. [In Ukrainian].

N. Ya. Tsiura, D. P. Kindzera, V. M. Atamanyuk, R. R. Hosovskyiy Lviv Polytechnic National University, Lviv, Ukraine

\section{DYNAMICS OF MOISTURE REMOVAL FROM IRON(II) SULFATE HEPTAHYDRATE DURING THE DRYING PROCESS BY FILTRATION METHOD}

In order to dehydrate iron(II) sulfate heptahydrate (iron sulphate), a filtration drying method has been proposed. Some theoretical aspects of drying method have been analyzed. The application and reasoning of this method of removing three molecules of moisture from iron(II) sulphate heptahydrate have been given. As a result of dehydration iron(II) sulfate heptahydrate by filtration method iron(II) sulfate tetrahydrate has been produced. The purpose of iron(II) sulfate tetrahydrate is its utilization as a secondary raw material in industry, in particular in the production of pigments. In accordance with the technological requirements and properties of the material, the range of changes in the parameters of the drying process is established and the methods of experiments have been described. The experimental and theoretical researches of kinetics and dynamics of moisture removal during filtration drying of iron(II) sulfate heptahydrate have been presented. The existence of a period of partial and a period of complete saturation of the thermal agent by the moisture have been determined experimentally. The dependence of dynamics of moisture removal on the height of layer and on the rate of filtration has been studied. Graphical dependences show the character of residual moisture in the layer of material and the change of temperature under the layer. The values of drying coefficients and drying rates have been calculated based on the generalization of research results based on the experimental data. It enabled proposing the equations for determination of humidity changes at the period of partial and at the period of complete saturation of the thermal agent by the moisture. Summary results allowed justifying the optimal technological parameters of the process, depending on the required performance and also calculating the basic dimensions and designing new drying equipment.

Keywords: drying velocity; humidity changes; dynamics; rate of filtration. 